\title{
A comparative study of extraterritorial jurisdiction over mergers in the EU and
}

\author{
US \\ Zongjin Li \\ School of Law,University of Glasgow, Glasgow G12 8QQ, United Kingdom \\ email: 1037053249@qq.com
}

Key words: Extraterritorial jurisdiction; the EU and US; Competition Law

\begin{abstract}
The aim of this paper is to evaluate whether extraterritorial jurisdiction over mergers can be justified, and to compare and contrast the legal practice in the EU and US. The extension of jurisdiction to foreign companies could benefit the protection of competition, while this could cause legal conflicts and hostility. Some suggestions towards the problems are proposed in this paper.
\end{abstract}

\section{Introduction}

In a global market, mergers and concentrations involving foreign companies could extend the anti-competitive effects to another part of the world outside where they are originated. To tackle effects, competition law regimes tend to assert jurisdiction extraterritorially. America is the first country establishing the 'effects doctrine' to extend its jurisdiction to the concentrations involving foreign companies. Similar to US, EU holds that the European Merger Regulation is applied extraterritorially when the merger is above a certain threshold. This approach could be beneficial to the interests of domestic industries and consumers as it could prevent the potential anti-competitive harm caused by the concentrations. However, it could cause legal conflicts between different regimes, and bring uncertainty to and increase financial and staff costs of foreign companies.

This essay seeks to identify the advantages and disadvantages of the assertion of extraterritorial jurisdiction on merger control. A further aim of this essay is to give possible suggestions to decrease the legal conflicts between different regimes and the costs of multiple notifications. For these purposes, firstly, the legislations and legal practice of US and EU will be introduced, then the benefits and problems of the extraterritorial assertion of jurisdiction on merger cases are demonstrated, and then possible suggestions are proposed. Finally, a conclusion will be given.

\section{Merger control laws in EU and US}

U.S. antitrust law is one designed to prevent anticompetitive mergers or acquisitions. Under the Hart-Scott-Rodino Act, the Federal Trade Commission and the Department of Justice review most of the proposed transactions that affect commerce in the United States and are over a certain size[1]. To limit the application of extraterritorial jurisdiction, there are rules of exempting certain acquisitions of non-U.S. companies from the premerger notification requirement imposed by the Hart-Scott-Rodino Act(hereinafter "HSR Act").According to the rule, when foreign assets are acquired by a foreign person, the merger would be exempted from the application of the pre-merger requirement, even if the sales into the US exceeds the certain dollar threshold attributable to the acquired assets[2] [3]. Also, the acquisition of voting securities of a foreign issuer by a foreign person would be exempt from the requirements of the act unless either the acquisition awards the issuer assets located in the U.S. or annual sells into the US exceeding a certain amount( as adjusted)[4].

The core doctrine establishing the extraterritorial application of merger control of US regime is known as the 'effects doctrine', which was built up in the Alcoa casein 1945[5]. In this case, Judge Learned Hand held that Sherman Act did apply to agreements, which were intended to affect US imports and did actually affect them[6]. To assert extraterritorial jurisdiction, two conditions should 
be met: (1) The performance of the foreign agreement must be "shown to have some effect" in the United States. (2) This must have been intended. Some states tended to be hostile to the US, as US regime expanded its jurisdiction to foreign companies in these states based on the effects doctrine, and this could damage the interests of these states. However, in Timberlane Lumber Co. v. Bank of America in 1976[7], Judge Choy recognized the effects doctrine laid down in Alcoa case, and also added the third test, which required the consideration of "whether the interests of, and links to the United States, including the magnitude of the effects on American foreign commerce are sufficiently strong, to justify an assertion of extraterritorial authority" [8]. This test could balance the interests of other parties in a merger case. Also, according to Judge Choy, more factors as following should be taken into consideration when deciding whether US courts assert extraterritorial jurisdiction:

the degree of conflict with foreign law or policy, the nationality or allegiance of the parties and the locations or principal places of business of corporations, the extent to which enforcement by either state can be expected to achieve compliance, the relative significance of effects on the United States as compared with those on elsewhere, the extent to which there is explicit purpose of harming or affecting American commerce, the foreseeability of such effect, and the relative importance to the violations charged of conduct within the United States as compared with conduct happening abroad.

In EU, the main legislative texts for merger decisions are the Council Regulation (EC) 139/2004(EUMR)[9] and the Implementing Regulation. The EUMR sets up rules for the assessment of concentrations, whereas the Implementing Regulation regulates procedural issues, such as notification[10]. The EUMR applies to 'concentrations' with a community dimension. According to the EUMR, a concentration has a community dimension when the turnovers of the undertakings fulfill one of the two tests. The first test is regulated in Article 1(2). If the total world turnover of all the concerned undertakings is over 5 billion EUR and at least two of the undertakings concerned each has a EUR 250 million turnover Community-wide[11]. In general, the term "concentration" refers to a change in control over another undertaking[12]. If Concentrations fail to reach the thresholds of the first test, this concentration would still fall within the community dimension if the turnovers of the undertakings involved could meet a supplementary test[13]. The EUMR does not impose any limitation on the extraterritorial jurisdiction application, which means the EU commission could assert jurisdiction over concentrations between foreign companies, which meet one of the two tests, without considering whether the concentrations have an actual or potential effect on the EU market[14]. However, in practice, EU commission holds that jurisdiction on agreement and practices can be asserted based on the economic effects produced within the EU in the case Candle Wsxes[15].

\section{Justification for extraterritorial jurisdiction over mergers}

The extraterritorial assertion of jurisdiction on mergers to some extent could be justified due to the protection of the interests of domestic industries and consumers. A merger might have substantial anti-competitive effects on the product market although the merged entity is outside the latter regime, as trade and competition are increasingly global. Such anti-competitive effects may occur when merged entity acquire the dominance position of a certain market, even the global market, and then abuse the dominance position to pursue illegal profits. To be specific, a merger may create a monopoly. A monopoly is normally a well-financed firm, which provides the firm with the opportunity to using predatory pricing to drive rivals out of business. Then the monopoly may charge a high price without losing customers [16]. Even if a merger does not result in a monopoly, it still could lead to a significant increase in the market power in a particular industry so that the merged entity could be more competent in raising price or restricting output than the undertakings before merger did[17]. In the case Gencor/ Lonrho [18], it was argued that considering the market for platinum is a world market, if the concentration produces anti-competitive effects, the effects would be felt in every part of the world where the platinum was sold[19]. It can be concluded that extraterritorial assertion of jurisdiction on mergers could prevent the potential damage of the 
welfare of domestic consumers and that of enterprises competing in the relevant market.

\section{Problems caused by extraterritorial jurisdiction}

However, applying the merger control law of one regime to an entity in another may cause legal conflicts. To be specific, a domestic regime could clear merger because the merger could possibly promote the efficiency of the merged entity by achieving economies of scale in production, [20] while a foreign regime could forbid the merger due to the creation of anti-competitive effects on the market of this foreign regime. The rationale for the former regime to clear a merger could possibly be that merger could increase the scale of domestic enterprises, even create 'national champion', and this could possibly be a goal of industry policy because it could be beneficial to the domestic welfare since the efficiency of the enterprises, even that of the industry could be significantly increased and local employment could be promoted. However, the reason for the latter regime to forbid the merger could possibly be that concentrations of foreign companies can increase entities' market power and the market power could raise competition concerns. To be specific, merged entities could possibly achieve high efficiency and if the entities export a huge number of products to a foreign country, they could drive the companies in this foreign country out of business. This could be the reason for some countries hold a hostile position to mergers involving foreign companies. As a result, different regimes may hold different attitudes towards a merger case[21]. In Gencor/ Lonrho[22], two companies incorporated in South Africa intended to merge and this concentration was ratified by South Africa, as no competition problem was found, after it was notified to the domestic authority. However, it was prohibited by EU commission on the basis that the merger would create a position of oligopolistic dominance[23].

Extraterritorial application of law may also create uncertainty and huge financial costs for a foreign company. In the EU regime, according to Article 4(1), concentrations which fall within the EU dimension should notify the committee before the implementation of the concentration[24]. This increases the cost of concentration behavior. According to Article 7(1) of EUMR, concentrations which fall within the EU dimension should not conduct the concentration unless its notification has been declared compatible with the common market. The pre-merger notification and suspension increases the costs and places more burden on the undertakings incorporated outside the EU[25]. As for the US regime, after the companies report a proposed merger deal, firstly, a preliminary review will be carried out to determine whether this deal raises any antitrust concerns. This review will last for 30 days(15 days in the case of a cash tender or bankruptcy transaction), unless the waiting period is terminated or declared to be expired. However, the merger parties could be asked to submit more information and wait an additional time period, if the authority regards it as necessary to base on to make a final decision whether and how the transaction will affect competition. The situation could be complex and there would be more time and financial costs for the company if more than one regime assert jurisdiction over the case. To be specific, if EU asserts jurisdiction on a company incorporated in the US, this American company would confront with extensive workload to fulfill the requirement reporting the concentration deal to EU authority, and also wait for a period before the EU commission makes a decision, even if the concentration deal is declared legal by US authorities.

\section{Suggestions for the problems}

A possible solution to the legal conflicts caused by extraterritorial assertion of jurisdiction could be consideration of the notion of 'international comity'. It is an international principle which requires every state in the world community to harmonize their behaviors and act in mutual respect. Showing respect to the executive, legislative, and judicial acts of other states is regarded as a significant aspect. This principle has been reflected in the case Timberlane Lumber Co. v. Bank of America[26]. In this case, the judge considered the interests of international comity before making a decision on the application of effects doctrine. Also, consideration of the interests of other countries was shown in the case Boeing/ McDonnell Douglas[27]. A clearance was given to two US aircraft 
manufacturers, Boeing and McDonnell (MDC) by US authority. Then the EU commission received the notification of concentration and objected to the concentration at first stance as the concentration would pose a potential threat to the EU market. However, the commission made a final decision giving a clearance to the concentration after Boeing gave certain commitments to the commission. Therefore, it could be concluded that international comity could possibly play a significant role in resolving legal conflicts caused by extraterritorial assertion of jurisdiction, although the international merger cases tend to be complex[28].

It is suggested that, to reduce the negative influence of multiple notification, extraterritorial adoption of pre-merger notification requirement under the Merger Regulation should be narrowed. The first reason would be that it is unfair for the undertakings which would have no potential effects on the EU market to bear the costs conformance with the notification procedure. By limiting the extraterritorial application of notification could reduce the financial burden on the parties of concentrations. The financial burden includes lawyers' fees, the costs of personnel conducting the information collection as well as other costs during the waiting period. However, it could be argued that this suggestion could be impractical since the EU authority could possibly be insensitive to reducing the compliance costs of non-EU undertakings. Nevertheless, this suggestion should be emphasized, as it would also to some extent relieve the Commission of substantial workload. Considering the number of the case and the complexity of analysis that the commission needs to review is surging, limiting the broad assertion of extraterritorial jurisdiction is needed, and this could avoid the problem of under staff. To some extent, US HSR Act would be a great model.

A possible solution to multiple assertions of jurisdiction could be imposing a treaty that sets forth a single legal standard enforced by a single enforcer. It was suggested that the World Trade Organization would be a proper authority to enforce merger control so that conflicts could possibly be decreased, as the parties that sign the treaty would tend to respect the decision made under the same legal standard. Also, the costs of notification could be decreased, since the entity that intends to merge would only notify the single authority instead of identifying all regimes that assert jurisdiction on the transaction. This would save the costs. However, few countries would give up their own sovereignty to a multinational authority considering that decision of merger cases tend to have substantial consequences[29]. Also, currently, it would not be possible for a single authority to assume the responsibility to conduct the investigation of substantial merger cases in a global scope, as the requirements of staff and financial resource to conduct the investigation would exceed the capability of a certain authority.

\section{Conclusion}

In conclusion, it is suggested that extraterritorial adoption of pre-merger notification requirements under the Merger Regulation should be narrowed, in order to reduce the negative influence of multiple notifications, imposing a treaty that set forth a single legal standard enforced by a single enforcer could be a possible solution to multiple assertion of jurisdiction. Also, the notion of 'international comity' should be considered as it could to some extent resolve the legal conflicts between different regimes.

\section{References}

[1] Federal Trade Commissionhttps://www.ftc.gov/news-events/media-resources/mergers-andcompetition/merger-review (accessed at 19/11/2015)

[2] Current law requires companies to report any deal that is valued at more than $\$ 76.3$ million to the agencies so they can be reviewed. Federal Trade Commissionhttps:/www.ftc.gov/news-events/ media-resources/mergers-and-competition/merger-review (assessed 19/11/2015)

[3] 16 C.F.R. §802.51(a).

[4] 16 C.F.R. §802.51(b).

[5] United States v. Aluminum Co of America, 148 F.2d 416 (2d Cir. 1945). In this case, The 
Second Circuit Court of Appeals held that the Sherman Act applied to a Canadian company which was involved in a cartel to fix production quotas in order to boost prices. Judge Learned Hand said: "it is settled law ... that any state may impose liabilities, even on persons not within its allegiance, for conduct outside its borders which has consequences within its borders."

[6] J.Alison, and S.Brenda. EU competition law: text, cases, and materials. Oxford University Press (UK), 2014,1260.

[7] Timberlane Lumber Co v. Bank of America, 549 F.2d 597(9th Cir.1976)

[8] Banks, J. D. "The Development of the Concept of Extraterritoriality under European Merger Law and Its Effectiveness Under the Merger Regulation Following the Boeing/McDonnell Douglas Decision 1997." European Competition Law Review 19 (1998): 306-311. 308

[9] Also, a number of Commission Notices are supplemented.

[10] A,Jones., and S.Brenda. EU competition law: text, cases, and materials. Oxford University Press (UK), 2014,1138.

[11] EUMR, Art.1(2).

[12] See Commission Notice on the concept of a concentration, [1998] O.J. C/66, at 5.

[13] EUMR, Art.1(3).(a) the combined aggregate worldwide turnover of all the undertakings concerned is more than EUR 2500 million;

(b) in each of at least three Member States, the combined aggregate turnover of all the undertakings concerned is more than EUR 100 million;

(c) in each of at least three Member States included for the purpose of point (b), the aggregate turnover of each of at least two of the undertakings concerned is more than EUR 25 million; and

(d) the aggregate Community-wide turnover of each of at least two of the undertakings concerned is more than EUR 100 million,

unless each of the undertakings concerned achieves more than two-thirds of its aggregate Community-wide turnover within one and the same Member State.

[14] Fiebig, R.Andre "International Law Limits on the Extraterritorial Application of the European Merger Control Regulation and Suggestions for Reform."European Competition Law Review 19 (1998): 323-331. 327

[15] COMP/ 39.181 Candle Waxes, 1 October 2008, [2009]

[16] HOVENKAMP, Herbert. Federal Antitrust Policy: the law of competition and its practice(4thedn, West Publishing, 2011), 371.

[17] A.Jones, S.Brenda. EU competition law: text, cases, and materials. Oxford University Press (UK), 2014,1132.

[18] Case IV/M.619, [1997] - Gencor/Lonrho

[19] Fox, M.Eleanor "The Merger Regulation and its Territorial Reach: Gencor Ltd v. Commission." European Competition Law Review 20 (1999): 334-336. 336

[20] Enterprises could obtain cost advantages from increasing the output, as the cost to produce per product will decrease considering fixed costs are spread out over more units of products. Other efficiencies of increasing the size of enterprises include marketing efficiency and capability to innovate and apply new technology.

[21] A.Ezrachi."Limitations on the Extraterritorial Reach of the European Merger Regulation(2001)." European Competition Law Review 22: 137-145.Competition Law

Review 22:137

[22] Case IV/M.619, [1997] - Gencor/Lonrho

[23] Broberg, P.Morten "The European Commission's Extraterritorial Powers in Merger Control." International and Comparative Law Quarterly 49.01 (2000): 172-182. 173

[24] ibid.,Art. 4, [1989] O.J. L395/1, at 4.

[25] A. Ezrachi,."Limitations on the Extraterritorial Reach of the European Merger Regulation'(2001)." European Competition Law Review 22: 142

[26] A.Jones, and S.Brenda. EU competition law: text, cases, and materials. Oxford University 
Press (UK), 2014,1260

[27] Boeing/ McDonnell Douglas

[28] Bavasso, A. E. "Boeing/McDonnell Douglas: Did the Commission Fly Too High?." European Competition Law Review 19 (1998): 243-248.

[29] Griffin, Joseph P. "Antitrust Aspects of Cross-Border Mergers and Acquisitions." European Competition Law Review 19 (1998): 12-20. 